\title{
The University of Kansas Law Review
}

ISSN-0083-4025

\begin{tabular}{lcc}
\hline Volume 69 & November 2020 & Number 1 \\
\hline CONTENTS & \\
ARTICLES &
\end{tabular}

Martin Dickinson: 48 Years of Dedicated

Service to KU Law.... Stephen W. Mazza

Getting it Right Isn't Enough: The Appellate

Court's Role in Procedural Justice.... Steve Leben

Dust in the Wind: Regulation as an Essential

Component of a Sustainable and Robust Wind

Program.

Warigia M. Bowman

45

The AI Author

in Litigation.

Yvette Joy Liebesman \& Julie Cromer Young

\section{COMMENTS}

ICE-D OUT: A Constitutional Relatedness Analysis

Of the Bonus Points Awarded to Jurisdictions

Cooperating with Federal Immigration Goals Ryan Kelly

Context to Overcome Definition: How the

Supreme Court Used Statutory Interpretation to

Define "Person" and "Sex" 